\title{
Exchange of carbonyl sulfide (COS) between the atmosphere and various soils in China
}

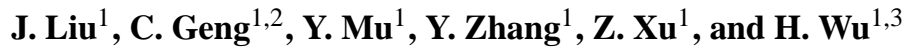 \\ ${ }^{1}$ State Key Laboratory of Environmental Chemistry and Ecotoxicology, Research Center for Eco-Environmental Sciences, \\ Chinese Academy of Sciences, Beijing, China \\ ${ }^{2}$ Chinese Research Academy of Environmental Sciences, Beijing, China \\ ${ }^{3}$ National Institute of Metrology, Beijing, China
}

Received: 22 October 2009 - Published in Biogeosciences Discuss.: 12 November 2009

Revised: 26 January 2010 - Accepted: 27 January 2010 - Published: 25 February 2010

\begin{abstract}
Using a dynamic enclosure, the exchange rates of carbonyl sulfide (COS) between the atmosphere and 18 soils from 12 provinces in China were investigated. The emission or uptake of COS from the soils was highly dependent on the soil type, soil temperature, soil moisture, and atmospheric COS mixing ratio. In general, with the only exception being paddy soils, the soils in this investigation acted as sinks for atmospheric COS under wide ranges of soil temperature and soil moisture. Two intensively investigated wheat soils and one forest soil had optimal soil temperatures for COS uptake of around $15^{\circ} \mathrm{C}$, and the optimal soil water content varied from $13 \%$ to $58 \%$. COS emission rates from the two paddy soils increased exponentially with increment of the soil temperature, and decreased with increasing the soil water content. However, negligible emission was found when the paddy soils were under waterlogging status. The observed compensation points for various soils were different and increased significantly with soil temperature. The laboratory simulation agreed with the preliminary field measurements for the paddy soil in Jiaxing, Zhejiang province.
\end{abstract}

\section{Introduction}

Carbonyl sulfide (COS), the most abundant and long-lived reduced sulfur gas in the troposphere, is an important precursor for the stratospheric sulfate aerosol layer (Crutzen, 1976; Hofmann, 1990; Engel and Schmidt, 1994) and thus has an impact on the earth's radiation budget as well as on ozone destruction (Turco et al., 1980; Solomon et al., 1993;

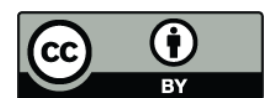

Correspondence to: $\mathrm{Y} . \mathrm{Mu}$

(yjmu@ rcees.ac.cn)
Roche et al., 1994; Andreae and Crutzen, 1997). Atmospheric sinks and sources of COS have aroused widely attention, and many studies have examined for atmospheric COS sinks and sources (Bartell, et al., 1993; Kesselmeier and Merk, 1993; Kesselmeier, et al., 1993; de Mello and Hines, 1994; Gries et al., 1994; Kuhn et al., 1999, 2000; Kettle et al., 2002; Xu et al., 2002; Geng and Mu, 2004; Sandoval-Soto et al., 2005; Yi et al., 2007, 2008; Van Diest and Kesselmeier, 2008).

Soils were previously considered to represent one of the dominant sources for atmospheric COS (Khalil and Rasmussen, 1984; Chin and Davis, 1993). However, recently, field studies and laboratory simulations have presented convincing evidence that soils act more as a sink than as a source for COS (Castro and Galloway, 1991; Fried et al., 1993; de Mello and Hines, 1994; Kesselmeier et al., 1999; Kuhn et al., 1999; Kettle et al., 2002; Geng and Mu, 2004; Yi et al., 2007, 2008; Van Diest and Kesselmeier, 2008). Earlier researchers investigating COS exchange usually used enclosure methods with COS-free sweep air (Aneja et al., 1979; Adams et al., 1981; Goldan et al., 1987; Lamb, et al., 1987; MacTaggart et al., 1987), which masked the potential of soils to act as a sink for sulfur compounds. In contrast, some other researchers used very high concentration of COS to study the potential of soils to take up COS (Bremner and Banwart, 1976; Kluczewski et al., 1985; Lehmann and Conrad, 1996), which also generated artificial COS concentration gradients. Therefore, earlier data should be checked for artifacts due to the use of inappropriate air mixtures for flushing enclosures.

Watts (2000) estimated COS deposition and emission rates for two different types of soils as $0.92 \pm 0.78 \mathrm{Tg} \mathrm{a}^{-1}$ (sink, "oxic" soils) and $0.02 \pm 0.01 \mathrm{Tg} \mathrm{a}^{-1}$ (source, "anoxic" soils). However, the estimate was only based on a few studies with limited soil types, especially in the case of "oxic" soils (only

Published by Copernicus Publications on behalf of the European Geosciences Union. 
two results from two types of soils were used as the basis for the estimation) and contained considerable uncertainty. Kesselmeier et al. (1999) were the first to parameterize the influencing factors of COS uptake by soil taken from arable land. Van Diest and Kesselmeier (2008) investigated COS exchanges between four kinds of soils (three arable soils from Germany, China, and Finland and one forest soil from Siberia) and the atmosphere for parameterization in relation to ambient COS concentration, soil water content, and temperature. They suggested that the uptake of COS depended on diffusivity, which was controlled by water-filled pore space (WFPS). The parameterization of COS uptake gave a clear clue as to how to reduce existing uncertainties in estimating COS uptake by different soils. Because COS exchange between soils and the atmosphere is largely dependent upon soil type, additional study is needed to reassess the parameterization of different soil types using the enclosure method with ambient air (Kesselmeier et al., 1999; Watts, 2000; Kettle et al., 2002; Sandoval-Soto et al., 2005; Van Diest and Kesselmeier, 2008).

The objective of this study was to compare the exchange rates of COS between the atmosphere and different types of soils in China. The factors affecting the exchange rates, i.e., temperature, soil moisture, and COS mixing ratio, were also investigated for five soils. Our results extend the data set and yield better insight into the role of different soils in the atmospheric COS budget.

\section{Materials and methods}

\subsection{Sampling sites}

Eighteen types of soil were sampled from 12 provinces in China (Fig. 1) covering about half of China's agricultural regions. Samples were taken from the top $5 \mathrm{~cm}$ of the soil profile and sieved to $<2 \mathrm{~mm}$ using a stainless steel sieve.

The characteristics of the five most intensively investigated soils were determined, and these are listed in Table 1. Soil characteristics were determined at the Beijing Academy of Agriculture \& Forestry Sciences using standard protocols (Liu, 1996). Samples were stored at $3{ }^{\circ} \mathrm{C}$ prior to investigation.

\subsection{Construction and performance of exchange enclosure}

A dynamic enclosure was used to measure the COS exchange rate from the different soils. The enclosure consisted of a stainless steel cylinder $(20 \mathrm{~cm}$ high $(\mathrm{H}), 18 \mathrm{~cm}$ inner diameter (ID) and with a 5-L volume) with an inner surface covered by a Teflon film to prevent any effects from contamination or adsorption. An inlet (perforated stainless steel ring) that allowed gas with fixed COS concentration into the enclosure was located near the bottom of the cylinder. The investigated soil was put into a glass dish (ID, $15 \mathrm{~cm}$ ) at the bottom of the enclosure. Soil temperature was controlled by putting the enclosure in a super-constant-temperature water boiler (CS501, Chongqing Testing Equipment Corporation, Chongqing, China). COS concentrations within the desired range for flushing the enclosure were obtained by mixing a purified compressed air (50 ppt COS) with highconcentration COS gas (5-50 ppb COS) from a glass flask $(10 \mathrm{~L})$. The flow rates of the purified compressed air and the high-concentration COS gas was controlled by two mass flow meters (SY-9506, Beijing Shengye Technologic Development Corporation, Beijing, China) with ranges of 0 $5 \mathrm{~L} \mathrm{~min}^{-1}$ and $0-100 \mathrm{~mL} \mathrm{~min}^{-1}$, respectively. Before being introduced into the enclosure, the mixed air was humidified by a water bubbler which was also placed inside the water boiler to prevent the soil samples from drying during the experiments. COS concentration from the exhaust of the water bubbler was analyzed by the GC-FPD every $10 \mathrm{~min}$, could achieve steady value (maximum $10 \%$ variation) after $30 \mathrm{~min}$. Then, all exchange rate measurements were conducted under the condition of the dynamic equilibrium. The total airflow rate through the enclosure was normally kept at $0.7-$ $0.8 \mathrm{~L} \mathrm{~min}^{-1}$.

The COS exchange rate (ER, pmol m $\mathrm{m}^{-2} \mathrm{~s}^{-1}$ or pmol $\mathrm{g}$ $(\mathrm{DW})^{-1} \mathrm{~h}^{-1}$ ) in the enclosure was calculated using the following equation:

$\mathrm{ER}=(V / A) \times\left(C_{\text {out }}-C_{\text {in }}\right)$ or $\mathrm{ER}=(V / W) \times\left(C_{\text {out }}-C_{\text {in }}\right)$,

where $V\left(\mathrm{~m}^{3} \mathrm{~h}^{-1}\right)$ is the steady flow rate of the flushing gas through the enclosure and $A\left(\mathrm{~m}^{2}\right)$ is the surface area of soil spread on the glass dish. $W(\mathrm{~g})$ is the dry weight of the applied soil, and $C_{\text {in }}$ and $C_{\text {out }}\left(\mathrm{pmol} \mathrm{m}^{-3}\right)$ are the COS concentrations in the inlet and outlet of the enclosure, respectively.

The influence of the soil mass relative to surface area (i.e., soil column height inside the enclosure) on the COS exchange was tested incrementally up to $200 \mathrm{~g}$ of fresh soil (two soils of lawn and winter wheat from Beijing, and one paddy soil from Jiaxing). We found a linear correlation between the COS exchange rate and soil mass up to $100 \mathrm{~g}$. This correlation shifted to a saturation-like exchange behavior with increased soil mass between $100 \mathrm{~g}$ and $200 \mathrm{~g}$. Therefore, all experiments were performed using only $100 \mathrm{~g}$ of soil. Soil water content was varied by air-drying soils and re-moistening them with deionization water.

The control experiments for the dynamic enclosure, in which the steel cylinder containing no soil sample, were conducted between 10 and $40^{\circ} \mathrm{C}$. Weak emissions of COS were found from the blank enclosure, especially when temperature was higher than $20^{\circ} \mathrm{C}$ (Fig. 2). To eliminate the background COS contribution, the blank COS exchange rate was subtracted from the total exchange rates measured from the soil samples. To verify our laboratory simulation for paddy field soil, we carried out a brief set of field measurements in Jiaxing, Zhejiang province, the collection site for our paddy soil sample. Two dynamic chambers were adopted for exchange rate measurements. Each dynamic chamber consists 
Table 1. The characteristics of five soil samples (W1: wheat soil in Beijing; W2: wheat soil in Zibo (Shandong Province); P1: Paddy soil in Jiaxing (Zhejiang Province); P2: Paddy soil in Guangzhou (Guangdong Province); F: forest soil in Beijing).

\begin{tabular}{|c|c|c|c|c|c|c|}
\hline Soil & $\mathrm{pH}$ & $\begin{array}{r}C_{\text {organic }} \\
\mathrm{g} / \mathrm{kg}\end{array}$ & $\begin{array}{r}N_{\text {total }} \\
\mathrm{g} / \mathrm{kg}\end{array}$ & $\begin{array}{r}P_{\text {total }} \\
\mathrm{g} / \mathrm{kg}\end{array}$ & $\begin{array}{r}S_{\text {total }} \\
\mathrm{g} / \mathrm{kg}\end{array}$ & $\begin{array}{l}S_{\text {effect }}^{\mathrm{a}} \\
\mathrm{mg} / \mathrm{kg}\end{array}$ \\
\hline W1 & 6.31 & 8.24 & 0.92 & 0.618 & 0.12 & 25.0 \\
\hline W2 & 7.74 & 15.1 & 1.13 & 0.783 & 0.40 & 94.8 \\
\hline P1 & 6.14 & 24.5 & 2.26 & 0.579 & 0.45 & 31.5 \\
\hline $\mathrm{P} 2$ & 6.42 & 29.1 & 2.42 & 0.860 & 0.65 & 56.2 \\
\hline $\mathrm{F}$ & 6.44 & 61.5 & 4.94 & 0.967 & 0.90 & 21.2 \\
\hline
\end{tabular}

a $S_{\text {effect }}$ : soil available sulfur $\left(S_{\text {effect }}\right)$ means the sulfur in the soil can be used for crops assimilation, including soluble sulfur and part of the adsorption sulfur and organic sulfur. It was measured by turbidimetry method after extraction from soils with $0.5 \mathrm{~mol} \mathrm{~L}^{-1}$ $\mathrm{NaHCO}_{3}$ (Liu, 1996).

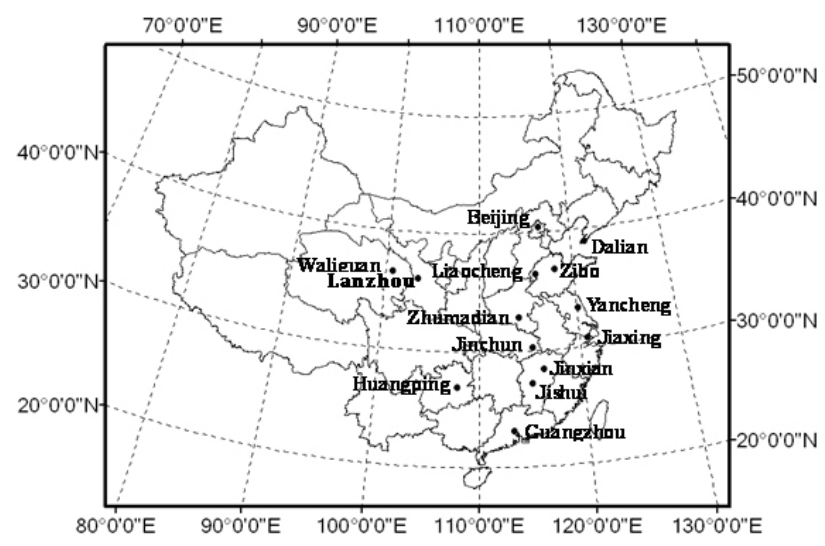

Fig. 1. Locations of sampling sites in this study.

of a Polyvinylchlorid tube $(30 \mathrm{~cm}(\mathrm{H}) \times 20 \mathrm{~cm}$ (ID)) that has an inner surface covered by Teflon film $(0.1 \mathrm{~mm})$. Four inlets of Teflon tubes were evenly connected to each chamber at the outside with heights of $5 \mathrm{~cm}$ above the bottom, and the other ends of the four tubes rose to $50 \mathrm{~cm}$ above ground. A minipump connected with an outlet at the top of the chamber was used to drive ambient air into the chamber. The flow rate was kept at $3.27 \mathrm{~L} \mathrm{~min}^{-1}$. During COS exchange rates measurements, one chamber was mounted on a pedestal $(15 \mathrm{~cm}$ $(\mathrm{H}) \times 20 \mathrm{~cm}$ (ID) with bottom open, the other one was also mounted on the same pedestal, but with bottom covered by Teflon film. The pedestal had a gutter around the outside of its upper rim that could be filled with water to make an airtight seal with the chamber. The pedestals for the chambers other than the reference one was inserted $10 \mathrm{~cm}$ into the investigated soil for one day before the exchange rate measurements. After flushing the chamber for 30 min with outside ambient air, air samples were collected into 2-L Teflon bags $(0.1 \mathrm{~mm}$ film) and analyzed within 3 days after collection.

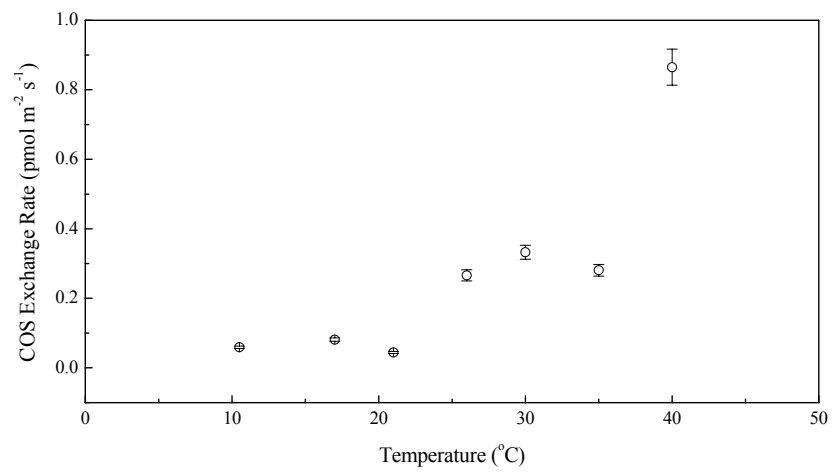

Fig. 2. COS exchange rates of the blank enclosure system (with glass dish) in relation to the temperature. The error bars are calculated from formula (2); each exchange rate measurement was conducted twice.

\subsection{COS analysis}

COS was sampled by cryogenic trapping and analyzed by means of a gas chromatograph (GC) equipped with a flame photometric detector (FPD) according to Hofmann et al. (1992). Detailed description of the method can be found in Mu et al. (2002, 2004). The detection limit for COS was approximately $0.88 \mathrm{pmol} \mathrm{L}^{-1}$ ( $800 \mathrm{~mL}$ gas sample). The relative precision of the method for COS was less than $6 \%$, and the recovery efficiency of COS was about $94 \%$ (Mu et al., 2002, 2004).

The following assumptions were made in calculating the errors of the exchange rates: $10 \%$ error for the COS measurements at the enclosure inlet $\left(\sigma_{\text {in }}\right)$ and the enclosure outlet $\left(\sigma_{\text {out }}\right), 5 \%$ error in the enclosure flow measurement $\left(\sigma_{Q}\right)$, and $1 \%$ error in the surface area determination or the soil mass determination $\left(\sigma_{A / W}\right)$. The total exchange rate error $\left(\sigma_{F}\right)$ can be obtained by using the error propagation method according to Doerffel (1984):

$\sigma_{F}=\sqrt{\frac{\left[\left(C_{\text {in }} \sigma_{\text {in }}\right)^{2}+\left(C_{\text {out }} \sigma_{\text {out }}\right)^{2}\right]}{\left(C_{\text {out }}-C_{\text {in }}\right)^{2}}+\sigma_{Q}^{2}+\sigma_{A / W}^{2}}$

\section{Results}

For all soil samples, we investigated COS exchange rates at the original moisture level and at two different temperature: $17^{\circ} \mathrm{C}$ and $25^{\circ} \mathrm{C}$. COS concentration was kept at around $500 \pm 80$ ppt. We derived COS deposition velocities for each soil sample using the measured exchange rates and the COS concentration.

Table 2 gives an overview of the exchange rate and deposition velocity measured at $17{ }^{\circ} \mathrm{C}$ and $25^{\circ} \mathrm{C}$ at original moisture levels for each of the investigated soils. It is evident that large difference in COS exchange rate and deposition velocity exist among the different soil types. The maximal 
Table 2. COS exchange rates (ER) and deposition velocities of various soils in China.

\begin{tabular}{|c|c|c|c|c|c|c|c|c|c|}
\hline Site & Plant type & $\begin{array}{l}\text { Parent } \\
\text { material }\end{array}$ & $\begin{array}{r}\text { Soil } \\
\text { moisture } \%^{a}\end{array}$ & $\begin{array}{r}\operatorname{ER}\left(17^{\circ} \mathrm{C}\right) \\
\mathrm{pmol} \mathrm{m}^{-2} \mathrm{~s}^{-1}\end{array}$ & $\begin{array}{r}\mathrm{ER}\left(25^{\circ} \mathrm{C}\right) \\
\mathrm{pmol} \mathrm{m}^{-2} \mathrm{~s}^{-1}\end{array}$ & $\begin{array}{r}\mathrm{ER}\left(17^{\circ} \mathrm{C}\right) \\
\mathrm{pmol} \mathrm{g}^{-1} \mathrm{~h}^{-1}\end{array}$ & $\begin{array}{r}\mathrm{ER}\left(25^{\circ} \mathrm{C}\right) \\
\mathrm{pmol} \mathrm{g}^{-1} \mathrm{~h}^{-1}\end{array}$ & $\begin{array}{r}\text { Deposition } \\
\text { velocity } \\
\mathrm{mm} \mathrm{s}^{-1}\left(17^{\circ} \mathrm{C}\right)\end{array}$ & $\begin{array}{r}\text { Deposition } \\
\text { velocity } \\
\mathrm{mm} \mathrm{s}^{-1}\left(25^{\circ} \mathrm{C}\right)\end{array}$ \\
\hline Jinxian, Jiangxi & badlands & Red earth & 19.0 & 0.061 & -2.84 & 0.049 & -1.84 & - & 0.12 \\
\hline Liaocheng, Shandong & cotton & Fluvo-aquic soil & 16.5 & -1.32 & -1.10 & -0.84 & -0.69 & 0.075 & 0.056 \\
\hline Yancheng, Jiangsu & cotton & Solonchak soil & 17.8 & -0.49 & -0.11 & -0.31 & -0.05 & 0.02 & 0.0051 \\
\hline Beijing & forest & Drab soil & 43.9 & -4.05 & -0.83 & -3.21 & -0.81 & 0.17 & 0.041 \\
\hline Waliguan, Qinghai & grass & Chestnut soil & 9.77 & -3.76 & -2.69 & -2.28 & -1.62 & 0.22 & 0.15 \\
\hline Beijing & lawn & Drab soil & 8.35 & -4.90 & -4.83 & -3.00 & -3.08 & 0.23 & 0.26 \\
\hline Liaocheng, Shandong & maize & Fluvo-aquic soil & 18.9 & -2.17 & -1.41 & -1.42 & -0.90 & 0.10 & 0.075 \\
\hline Jiaxing, Zhejiang & paddy & Drab soil & 20.7 & 0.44 & 1.19 & 0.27 & 0.63 & - & - \\
\hline Guangzhou, Guangdong & paddy & Paddy soil & 19.4 & 0.69 & 12.9 & 0.46 & 8.56 & - & - \\
\hline Jinchun, Hubei & paddy & Red earth & 23.2 & 0.57 & 2.00 & 0.40 & 1.34 & - & - \\
\hline Jishui, Jiangxi & paddy & Red earth & 18.8 & -2.04 & 0.29 & -1.33 & 0.22 & 0.077 & - \\
\hline Yancheng, Jiangsu & paddy & Solonchak soil & 19.7 & -0.41 & -0.10 & -0.27 & -0.04 & 0.018 & 0.0044 \\
\hline Huangping, Guizhou & paddy & Yellow earth & 27.8 & -3.20 & -3.56 & -2.25 & -2.15 & 0.15 & 0.19 \\
\hline Lanzhou, Gansu & plum blossom & Grey-drab soil & 10.7 & -2.46 & -2.18 & -1.51 & -1.32 & 0.12 & 0.096 \\
\hline Dalian, Liaoning & wheat & Burozem & 9.13 & -2.10 & -2.76 & -1.26 & -1.66 & 0.096 & 0.17 \\
\hline Zibo, Shandong & wheat & Burozem & 17.2 & -4.32 & -2.73 & -2.80 & -1.66 & 0.18 & 0.13 \\
\hline Beijing & wheat & Drab soil & 8.00 & -1.04 & -0.73 & -0.69 & -0.44 & 0.052 & 0.031 \\
\hline Zhumadian, Henan & wheat/paddy & Yellow-brown & 13.1 & -0.77 & 0.02 & -0.48 & 0.032 & 0.039 & - \\
\hline
\end{tabular}

${ }^{\mathrm{a}}$ Soil moisture $\%=$ water $(\mathrm{g}) /$ soil (dry weight, $\left.\mathrm{g}\right) \times 100 \% ;{ }^{\mathrm{b}}$ Deposition velocity=COS exchange rate/the outlet concentration of COS.

emission and uptake rates were $12.9 \mathrm{pmol} \mathrm{m}^{-2} \mathrm{~s}^{-1}$ at $25^{\circ} \mathrm{C}$ (paddy soil) and $-4.90 \mathrm{pmol} \mathrm{m}^{-2} \mathrm{~s}^{-1}$ at $17^{\circ} \mathrm{C}$ (lawn soil).

Three of the paddy soil samples acted as COS sources at both $17^{\circ} \mathrm{C}$ and $25^{\circ} \mathrm{C}$, whereas two acted as COS sinks. COS uptake (sink) was observed at $17^{\circ} \mathrm{C}$ for the paddy soil from Jishui (Jiangxi province), although a weak emission (source) was observed at $25^{\circ} \mathrm{C}$. The same behavior was observed for the paddy soil from Zhumadian (Henan province), where wheat and rice are cultivated in rotation. In contrast to the paddy soils, all other soils acted as COS sinks.

To investigate the influence of COS concentration, soil temperature, and moisture on COS exchange, we focused on five soil samples. Two of these were from northern wheat land soils: Beijing (W1) and Zibo (Shandong province) (W2); two were from southern paddy-field soils: Jiaxing (Zhejiang province) (P1) and Guangzhou (Guangdong province) (P2); and one was from northern forest (larch)-land soil: Beijing (Lingshan) (F).

\subsection{COS exchange rates under varying COS concentrations}

The exchange rate of COS and its dominant direction are recognized to strongly depend upon ambient COS concentration (Conrad, 1994; Lehmann and Conrad, 1996; Kesselmeier et al., 1999) and a so-called compensation point (under a typical ambient concentration, the consumption and production balance each other, and the net exchange rate is zero; Kesselmeier et al., 1999). When the ambient concentration is above the compensation point, net deposition occurs. Whereas when concentrations are below the compensation point, net emission occurs. The compensation point, therefore, is an important parameter in judging exchange direction. To obtain the compensation points for the differ- ent soils in this study, the exchange rates from the investigated soils were measured under varying COS concentrations, from $50 \mathrm{ppt}$ to $1400 \mathrm{ppt}$, at $17^{\circ} \mathrm{C}$ and $25^{\circ} \mathrm{C}$ (Fig. 3). Linear correlations between COS exchange rate and COS concentration were found for all investigated soil samples. The compensation points for the five soils were determined by the linear regression as the abscissa intercept of the regression line (Kesselmeier et al., 1999). The compensation points, ordinate intercepts, slopes and correlation coefficients of the linear correlation analysis are listed in Table 3, together with the values reported in the literature for other soils.

For the paddy soils, P1 and P2, the compensation points were around the global average concentration of $500 \mathrm{ppt}$ at $17^{\circ} \mathrm{C}$, but were much greater at $25^{\circ} \mathrm{C}$. These soils can be considered as COS sources, especially when their temperature is above $17^{\circ} \mathrm{C}$.

For other soils (W1, W2, and F), the compensation points were found to be below the global average COS concentration at $17^{\circ} \mathrm{C}$ and $25^{\circ} \mathrm{C}$. As for the forest soil (F), the compensation point was $80 \mathrm{ppt}$ at $17^{\circ} \mathrm{C}$, similar to the data obtained during field measurements on an oak woodland soil in California (Kuhn et al., 1999). Consequently, these soils should act as COS sinks under natural conditions. Additionally, the compensation points for the five soil types were higher at $25^{\circ} \mathrm{C}$ than they were at $17^{\circ} \mathrm{C}$, indicating that an increase in temperature may favor the production of COS.

\subsection{COS exchange rates under varying temperatures}

Temperature has been shown to be an important factor governing sulfur emission as microorganism activity is enhanced (Hill et al., 1978; Adams et al., 1981; MacTaggart et al., 1987; Kesselmeier et al., 1999). Therefore, we investigated COS exchange between the soil and atmosphere under 
Table 3. COS compensation point (CP), the ordinate intercepct, slope and correlation coefficent $(R)$ of the regression line of the observed COS exchange rates versus concentrations in this study compared with other studies (P1: Paddy soil in Jiaxing (Zhejiang Province); P2: Paddy soil in Guangzhou (Guangdong Province); W1: wheat soil in Beijing; W2: wheat soil in Zibo (Shandong Province); F: forest soil in Beijing).

\begin{tabular}{|c|c|c|c|c|c|c|c|c|c|c|}
\hline \multirow[b]{2}{*}{ Soil } & \multirow{2}{*}{$\begin{array}{l}\text { Water } \\
\text { content } \\
(\%)^{a}\end{array}$} & \multirow[t]{2}{*}{$\mathrm{CP}(\mathrm{ppt})$} & \multirow{2}{*}{\multicolumn{2}{|c|}{$\begin{array}{l}\text { Ordinate } \\
\text { intercept Slope } \\
\qquad 17^{\circ} \mathrm{C}\end{array}$}} & \multirow[t]{2}{*}{$R$} & \multirow[t]{2}{*}{$\mathrm{CP}(\mathrm{ppt})$} & \multirow[t]{2}{*}{$\begin{array}{l}\text { Ordinate } \\
\text { intercept } \\
25\end{array}$} & \multirow{2}{*}{$\begin{array}{l}\text { Slope } \\
\text { C }\end{array}$} & \multirow[t]{2}{*}{$R$} & \multirow[t]{2}{*}{ Reference } \\
\hline & & & & & & & & & & \\
\hline W1 & 8.00 & 255 & 1.054 & -0.0041 & -0.997 & 267 & 1.454 & -0.0055 & -0.999 & This study (laboratory) \\
\hline W2 & 17.2 & 120 & 1.413 & -0.0118 & -0.997 & 149 & 2.260 & -0.0152 & -0.999 & This study (laboratory) \\
\hline P1 & 20.7 & 491 & 4.125 & -0.0084 & -0.995 & 765 & 5.292 & -0.0069 & -0.998 & This study (laboratory) \\
\hline P2 & 19.4 & 572 & 4.388 & -0.0077 & -0.995 & 780 & 10.048 & -0.0129 & -0.998 & This study (laboratory) \\
\hline $\mathrm{F}$ & 43.9 & 80 & 0.775 & -0.0097 & -0.998 & 225 & 2.748 & -0.0122 & -0.997 & This study (laboratory) \\
\hline Oak woodland & & $<100$ & & & & & & & & Kuhn et al. (1999) (field) \\
\hline Sandy clay soil & & $\sim 53$ & & & & & & & & $\begin{array}{l}\text { Kesselmeier et al. (1999) } \\
\text { (laboratory) }\end{array}$ \\
\hline Forest soil & & & & & & 785 & & & & $\begin{array}{l}\text { Conrad and Meuser (2000) } \\
\text { (laboratory) }\end{array}$ \\
\hline Rape field soil & & & & & & 1470 & & & & $\begin{array}{l}\text { Conrad and Meuser (2000) } \\
\text { (laboratory) }\end{array}$ \\
\hline
\end{tabular}

a The water content of the soil is the original as found in the field.

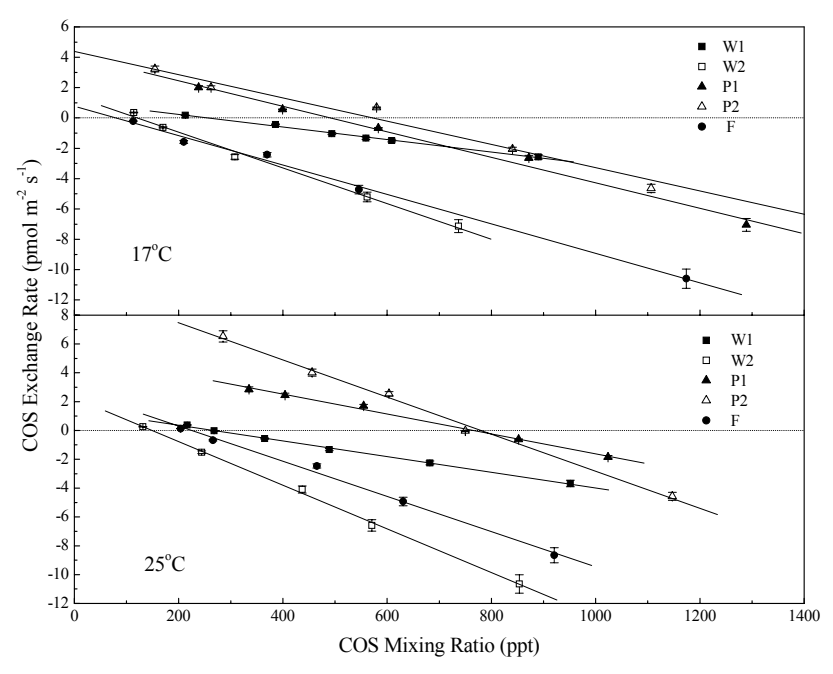

Fig. 3. COS exchange rates under different $\mathrm{COS}$ mixing ratios at 17 and $25^{\circ} \mathrm{C}$. (W1: wheat soil in Beijing, $8.00 \%$ moisture; W2: wheat soil in Zibo (Shandong Province), 17.2\% moisture; P1: Paddy soil in Jiaxing (Zhejiang Province), 20.7\% moisture; P2: Paddy soil in Guangzhou (Guangdong Province), 19.4\% moisture; F: forest soil in Beijing, $43.9 \%$ moisture). The error bars are calculated from formula (2); each exchange rate measurement was conducted twice.

varying temperatures $\left(1^{\circ} \mathrm{C}\right.$ to $\left.40^{\circ} \mathrm{C}\right)$. Figure 4 shows the result of $\mathrm{COS}$ exchange rates from the five soils under different temperatures at constant pressure and with a concentration of $500 \pm 80 \mathrm{ppt}$ COS in the air used to flush the enclosure. The wheat (W1 and W2) and forest (F) soils showed increased uptake (sink) with increasing temperature to an optimum at $15-20^{\circ} \mathrm{C}$, followed by a sharp decrease at higher tempera- tures. These results support the data obtained by Kesselmeier et al. (1999), who found an optimum temperature between 16 and $20^{\circ} \mathrm{C}$ for $\mathrm{COS}$ uptake. When the soil temperature was above $25^{\circ} \mathrm{C}$, weak emissions were measured from the $\mathrm{W} 1$ and $\mathrm{F}$ soils, whereas $\mathrm{W} 2$ remaned negative (uptake).

Carbonic anhydrase (CA) has been recognized as the key enzyme for the uptake of COS by different biological organisms (Chengelis and Neal, 1979; Chengelis and Neal, 1980; Miller et al., 1989; Badger and Price, 1990; Protoschill-Krebs and Kesselmeier, 1992; Protoschill-Krebs et al., 1995; Protoschill-Krebs et al., 1996; Kesselmeier et al., 1999). As mentioned by Kesselmeier et al. (1999), the activity of the enzyme should be responsible for the variation of COS exchange rates under different temperatures. de Mello (1992) found that the net consumption rate of COS in Sallie's Fen decreased from $\sim 50$ to $15 \mathrm{nmol} \mathrm{m}^{-2} \mathrm{~h}^{-1}$ (13.9$4.17 \mathrm{pmol} \mathrm{m}^{-2} \mathrm{~s}^{-1}$ ) as temperature increased from $\sim 16$ to $30^{\circ} \mathrm{C}$.

For paddy soils (P1 and P2), the exchange rate of COS was around 0 at low temperatures (for $\mathrm{P} 1$ below $15^{\circ} \mathrm{C}$, for $\mathrm{P} 2$ below $10^{\circ} \mathrm{C}$ ), whereas at higher temperatures, the emission was obvious and increased exponentially with increasing temperature. The relationships between COS emission rate $(F)$ and temperature $\left(T,{ }^{\circ} \mathrm{C}\right)$ for the paddy soils of $\mathrm{P} 1$ and $\mathrm{P} 2$ under the experimental soil moistures fitted the following equations:

$$
\begin{aligned}
& F_{\mathrm{P} 1}=\exp (0.126 \times T-2.26), R=0.997 \\
& F_{\mathrm{P} 2}=\exp (0.0884 \times T+0.195), R=0.995 .
\end{aligned}
$$

These relationships between COS exchange rate and soil temperature were inconsistent with the empirical algorithmic 


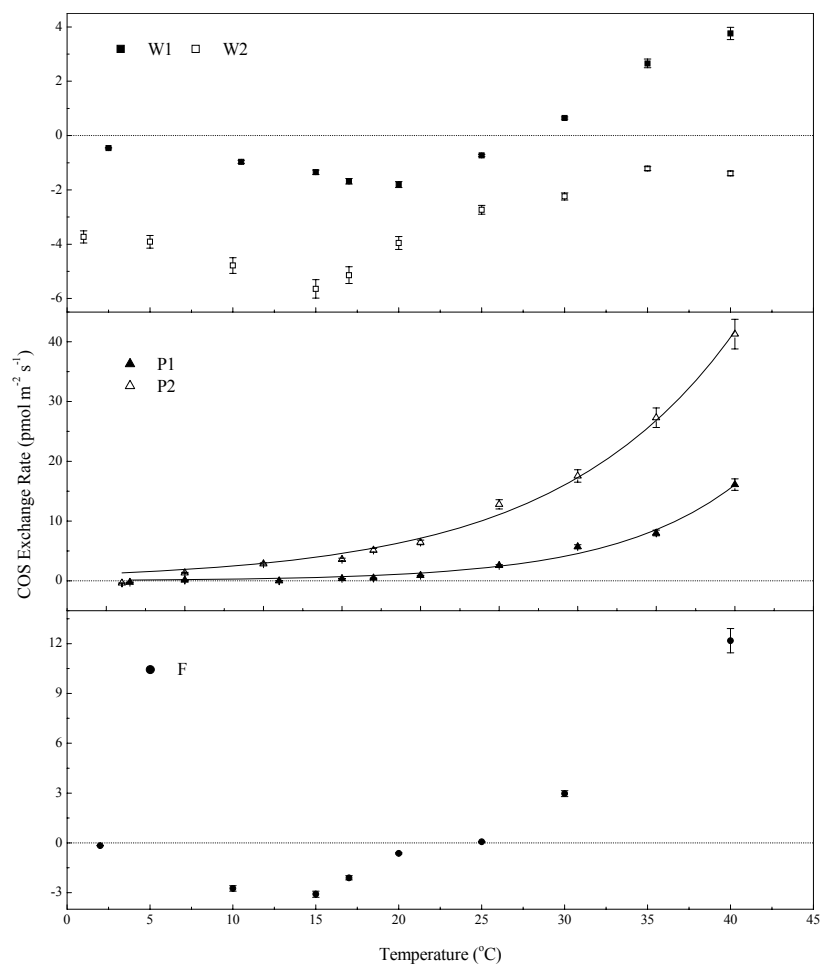

Fig. 4. COS exchange rates in relation to soil temperature. (W1: wheat soil in Beijing, $8.00 \%$ moisture; W2: wheat soil in Zibo (Shandong Province), 17.2\% moisture; P1: Paddy soil in Jiaxing (Zhejiang Province), 20.7\% moisture; P2: Paddy soil in Guangzhou (Guangdong Province), 19.4\% moisture; F: forest soil in Beijing, $43.9 \%$ moisture). The error bars are calculated from formula (2); each exchange rate measurement was conducted twice.

model developed by Conrad (1994) and Kesselmeier et al. (1999) for several kinds of soils.

\subsection{COS exchange rates under varying soil moistures}

Soil water content is also a critical parameter controlling the exchange of trace gases (Conrad, 1995; Meixner et al., 1997; Kesselmeier et al., 1999), because it influences chemical, physical, and biological processes. The exchange rates of COS under varying soil water contents were also determined in this study under the optimal temperature at $17^{\circ} \mathrm{C}$. A cool environment allowed for several repetitions of the measurements with negligible water loss $(0.3-0.8 \%)$. Again, we used air with a COS concentration of $500 \pm 80 \mathrm{ppt}$, and the results are shown in Fig. 5.

With only one exception for W2 at low moisture content of $5.66 \%$, both $\mathrm{W} 1$ and $\mathrm{W} 2$ acted as a sink for atmospheric COS with varying the soil water content from $1.46 \%$ to $46.5 \%$. The optimum water contents for $\mathrm{W} 1$ and $\mathrm{W} 2$ were found to be $13.4 \%$ and $23.0 \%$, respectively. The maximum uptake rate for $\mathrm{W} 2$ was higher by a factor of 5 than that for $\mathrm{W} 1$. As for the forest soil (F), net emission was observed when

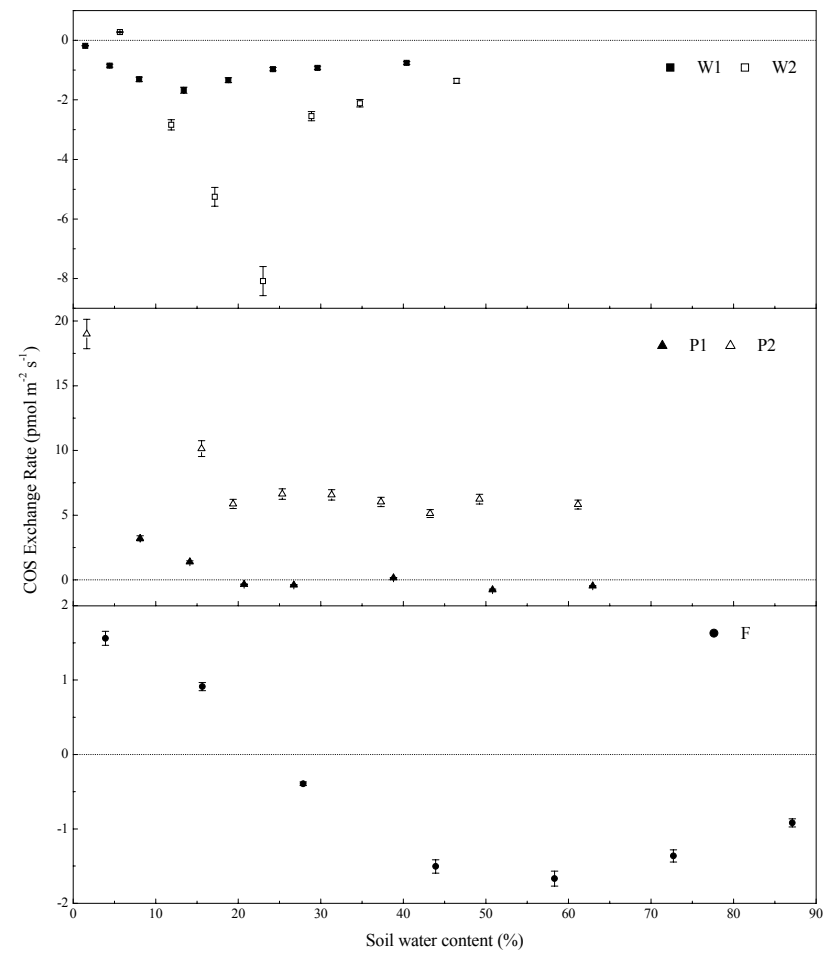

Fig. 5. COS exchange rates in relation to soil water content at $17^{\circ} \mathrm{C}$. (W1: wheat soil in Beijing; W2: wheat soil in Zibo (Shandong Province); P1: Paddy soil in Jiaxing (Zhejiang Province); P2: Paddy soil in Guangzhou (Guangdong Province); F: forest soil in Beijing). The error bars are calculated from formula (2); each exchange rate measurement was conducted twice.

soil water content was below $20 \%$, whereas uptake increased with increasing soil water content, up to optimum at $58.3 \%$ water content.

The two paddy soils (P1 and P2) showed decreasing COS emission with increasing soil water content until the exchange rates reached a steady state when soil water content was above $20 \%$. For P1, the steady exchange rate was about $0 \mathrm{pmol} \mathrm{m}^{-2} \mathrm{~s}^{-1}$, and for $\mathrm{P} 2$, the steady exchange rate was about $6 \mathrm{pmol} \mathrm{m}^{-2} \mathrm{~s}^{-1}$. Paddy soils are constantly waterlogged during rice growing season, the effects of waterlogging on COS exchange rates from the paddy soils were also investigated. No evident COS exchange was found after watering the paddy soils of P1 and P2 with de-ionized water to full saturation (soil surface covered with a water film), indicating that water cover prevents gas exchange with the atmosphere. It should be noted that the incubation of the soils under this condition lasted for less than $2 \mathrm{~h}$. Therefore, the zero exchange rate observed in this study might be due to the non-equilibrium of COS between the soils and the water.

COS exchange rates were also investigated in the paddy field of Jiaxing, Zhejiang province. The measured exchange rates, soil temperatures, the actual ambient COS concentration in the field, and soil water contents for three patches are 
Table 4. Field measurements for COS exchange rates from the paddy soil in Jiaxing, Zhejiang province.

\begin{tabular}{lllll}
\hline Patch & $\begin{array}{l}\text { Soil temperature } \\
\left({ }^{\circ} \mathrm{C}\right)\end{array}$ & $\begin{array}{l}\text { Soil water } \\
\text { content }(\%)\end{array}$ & $\begin{array}{l}\text { Ambient COS } \\
\text { concentration }(\mathrm{ppt})\end{array}$ & $\begin{array}{l}\text { Exchange Rate } \\
\left(\mathrm{pmol} \mathrm{m}^{-2} \mathrm{~s}^{-1}\right)\end{array}$ \\
\hline 1 & 22 & 19.6 & 3008 & $-57.9($ sink) \\
& \multirow{2}{*}{26} & 25.3 & 1390 & 19.6 (source) \\
& 26 & & 1695 & 26.8 (source) \\
3 & 24 & 31.0 (under waterlogging) & 1866 & 18.0 (source) \\
& & & 1764 & $-2.11($ sink) \\
\end{tabular}

listed in Table 4. In general, the field measurements agreed with the laboratory simulation. As shown in Table 4, COS exchange rate and its direction on the paddy soil strongly depend on ambient COS concentration. The strength of COS emission was much higher at $26^{\circ} \mathrm{C}$ than at $22^{\circ} \mathrm{C}$, although the water content was greater in the patch with soil temperature of $26^{\circ} \mathrm{C}$ than the patch of $22^{\circ} \mathrm{C}$. COS exchange rates under waterlogged conditions were also close to zero. The compensation point for the paddy soil from Jiaxing obtained by laboratory simulation was about $765 \mathrm{ppt}$ at $25^{\circ} \mathrm{C}$ (Table 3). However, obvious emission was observed by field measurements when ambient COS concentration was around 1500 ppt. The soil samples were strongly disturbed by sampling and treatments, e.g., the soils would become loose after sieving, and the redox potential of the soils would become higher due to the increasing probability of the air contacting with the soils. The influence of treatments on the investigated paddy soils may be more serious than the wheat soils, because the field paddy soils are always under anoxic condition. The increasing redox potential of the paddy soils would result in less COS production rate and lower compensation points, and the compensation points for the two paddy soils obtained by this study only represented their lower limits.

It should be mentioned that the ambient COS concentration in Jiaxing was extremely high; it was higher than the background COS concentration by a factor of 3 . The memory effect of the Teflon bags was checked by using the ambient air of Beijing three times, and an increment in COS concentration of about $10 \%$ was found during three days' storage. The high COS concentration in the field may be ascribed to the strong COS emission by the soil, the direct sources from a power plant about 1 kilometer away and a pig factory nearby the field.

\section{Discussion}

Paddy soils, which are always in a waterlogged condition, tend toward "anoxic" conditions. The laboratory simulation and short-term field measurements in this study further confirmed that most paddy soils act as sources of atmospheric
COS. COS emission from these types of soil have been recognized previously (Devai and Delaune, 1995; Kanda et al., 1992; Yang et al., 1996, 1998; Yi et al., 2008). Yang et al. (1998) found that COS mainly exhibited emission (only sometimes with uptake) from a paddy field (including rice plant) in Nanjing. Kanda et al. (1992) also observed net COS emission from a pay field in Japan after harvest when the paddy soil was dry. The preliminary field measurement in this study supported their findings, because strong COS emission potential of the paddy soils during non-waterlogged period (Table 4). The results of laboratory simulation in this study indicated that COS emission potential (the compensation points and the emission rates under various conditions) of the paddy soil from Guangzhou was much higher than the paddy soil from Jiaxing (Fig. 4). However, Yi et al. (2008) observed net sink of COS from the paddy soil of Guangzhou (the paddy soil of P2 in this study was from the same field) during non-waterlogged period, which was inconsistent with our field measurement and those investigated by Kanda et al. (1992) and Yang et al. (1998).

The emission rates from the two paddy soils investigated in this study decreased significantly as the soils' water content increased, especially when the soils were waterlogged. As for waterlogged soils, the laboratory simulation in this study may underestimate COS emission strength due to short time incubation. However, the field measurement for the waterlogged paddy soil (it was under waterlogged status for at least one month) in Jiaxing was in good agreement with the laboratory simulation. The results of this study for the waterlogged soil were inconsistent with previous studies both on field measurements (Kanda et al., 1992; Yang et al., 1998; Yi et al., 2008) and laboratory simulation (Devai and DeLaune, 1995; Yang et al., 1996). In addition to the short time incubation for laboratory simulation, the dynamic chamber setup used in this study was responsible for underestimation of COS emission from the waterlogged soil. Gas exchange between the air and water surface mainly depends on the degree of turbulence in the fluids (Liss and Slater, 1974). Compared with those of static chambers using fans for mixing the air (Kanda et al., 1992; Yi et al., 2008) and that using purge method (Devai and DeLaune, 1995), the turbulence of 
the interface between the air and water under the steady and slow air flow rate in the dynamic chambers might be negligible. In addition, the photochemical production of COS in water covered by transparent static chambers (Yi et al., 2008) made of Teflon film may also result in strong COS emission for the waterlogged soil because a large quantity of COS precursor(s), which is/are easily converted to COS under sunlight, existed in water system (Andreae and Ferek, 1992; Mu et al., 2004).

With the exception of paddy soils, all soils investigated in this study acted as sinks for atmospheric COS, the range of exchange rates was $0-(-4.90) \mathrm{pmol} \mathrm{m}^{-2} \mathrm{~s}^{-1}$, which agrees with field experiments: $0-(-6.52) \mathrm{pmol} \mathrm{m}^{-2} \mathrm{~s}^{-1}$ (Geng and $\mathrm{Mu}, 2004)$ for lawn soil in Beijing, China; -1.4$(-8.4) \mathrm{pmol} \mathrm{m}^{-2} \mathrm{~s}^{-1}$ for un-vegetated forest soil (Castro and Galloway, 1991); and -1.5-(-10.3) $\mathrm{pmol} \mathrm{m}^{-2} \mathrm{~s}^{-1}$ for arable soil (Kesselmeier, et al., 1999). The large difference for COS exchange rates among different soils as well as the complicated influencing factors indicated that the estimations of COS emission from "oxic" soils based on only two types of soils must be made with caution (Watts, 2000).

Van Diest and Kesselmeier (2008) investigated COS exchanges between four kinds of soils and the atmosphere and found the same optimal COS uptake at 19\% WFPS for the three different boreal soils (two arable soils from China and Finland and one forest soil from Siberia). Supposing the bulk density of the investigated soils were about $1 \mathrm{~g} \mathrm{~cm}^{-3}$ (the bulk densities of the investigated soils were not measured), WFPS can be calculated according to the general particle density using the formula adopted by Van Diest and Kesselmeier (2008). The calculated WFPS value of optimal COS uptake for W1 soil was $21.5 \%$ which is coincident with that of Van Diest and Kesselmeier (2008). However, the values for W2 (36.9\%) and F (93.6\%) soils were much higher than $19 \%$, indicating large difference of the optimal WFPS values among various soils from boreal soils.

\section{Conclusions}

Large differences in COS exchange were observed among the 18 types of soil samples from 12 provinces in China investigated in this study. Soil temperature, soil water content, and COS concentration are important influencing factors for the direction and the magnitude of COS exchange. The compensation points for various soils were significantly different and were strongly dependent upon soil temperature. Most agricultural soils, except for paddy soils, should be considered as COS sinks under natural conditions.

Acknowledgements. This work was financially supported by the Chinese National Natural Science Foundation (20977097, 40830101, 40875082 and 20577064), the Chinese Academy of Sciences (KZCX2-YW-Q02-03), the National water special project (2008ZX07421-001 and 2009ZX07210-009), the Platform Construction of Introducing Central Resources in Beijing (PXM2008_178305_06995) and the National Basic Research and Development Program 973 (2010CB732304, 2005CB422201).

Edited by: J. Kesselmeier

\section{References}

Adams, D. F., Farwell, S. O., Robinson, E., Pack, M. R., and Bamesberger, W. L.: Biogenic sulfur source strengths, Environ. Sci. Technol., 15, 1493-1498, doi:10.1021/es00094a012, 1981.

Andreae, M. O. and Crutzen, P. J.: Atmospheric aerosols: biogeochemical sources and role in atmospheric chemistry, Science, 276, 1052-1058, doi:10.1126/science.276.5315.1052, 1997.

Andreae, M. O. and Ferek, R. J.: Photochemical production of carbonyl sulfide in seawater and its emission to the atmosphere, Global Biogeochem. Cy., 6, 175-183, doi:10.1029/91GB02809, 1992.

Aneja, V. P., Overton Jr., J. H., Cupitt, L. T., Durham, J. L., and Wilson, W. E.: Direct measurements of emission rates of some atmospheric biogenic sulfur compounds, Tellus, 31, 174-178, 1979.

Badger, M. R. and Price, G. D.: Carbon oxysulfide is an inhibitor of both $\mathrm{CO}_{2}$ and $\mathrm{HCO}_{3}^{-}$uptake in the cyanobacterium synechococcus PCC7942, Plant Physiol., 94, 35-39, doi:10.1104/pp.94.1.35, 1990.

Bartell, U., Hofmann, U., Hofmann, R., Kreuzburg, B., Andreae, M. O., and Kesselmeier, J.: $\mathrm{COS}$ and $\mathrm{H}_{2} \mathrm{~S}$ fluxes over a wet meadow in relation to photosynthetic activity: an analysis of measurements made on 6 September 1990, Atmos. Environ., 27A, 1851-1864, doi:10.1016/0960-1686(93)90290-F, 1993.

Bremner, J. M. and Banwart, W. L.: Sorption of sulfur gases by soils, Soil Biol. Biochem., 8, 79-83, doi:10.1016/00380717(76)90068-7, 1976.

Castro, M. S. and Galloway, J. N.: A comparison of sulfur-free and ambient air enclosure techniques for measuring the exchange of reduced sulfur gases between soils and the atmosphere, J. Geophys. Res., 96, 15427-15437, doi:10.1029/91JD01399, 1991.

Chengelis, C. P. and Neal, R. A.: Hepatic carbonyl sulfide metabolism, Biochem. Biophys. Res. Commun., 90, 993-999, doi:10.1016/0006-291X(79)91925-9, 1979.

Chengelis, C. P. and Neal, R. A.: Studies of carbonyl sulfide toxicity: Metabolism by carbonic anhydrase, Toxicol. Appl. Pharmacol., 55, 198-202, doi:10.1016/0041-008X(80)90236-7, 1980.

Chin, M. and Davis, D. D.: Global sources and sinks of OCS and $\mathrm{CS}_{2}$ and their distributions, Global Biogeochem. Cy., 7, 321337, doi:10.1029/93GB00568, 1993.

Conrad, R. and Meuser, K.: Soils contain more than one activity consuming carbonyl sulfide, Atmos. Environ., 34, 3635-3639, doi:10.1016/S1352-2310(00)00136-9, 2000.

Conrad, R.: Compensation concentration as a critical variable for regulating the flux of trace gases between soil and atmosphere, Biogeochemistry, 27, 155-170, doi:10.1007/BF00000582, 1994.

Conrad, R.: Soil microbial processes and the cycling of atmospheric trace gases, Phil. Trans. Roy. Soc. Lond. A, 351, 219230, doi:10.1098/rsta.1995.0030, 1995.

Crutzen, P. J.: The possible importance of CSO for the sulfate layer of the stratosphere, Geophys. Res. Lett., 3, 73-76, doi:10.1029/GL003i002p00073, 1976. 
de Mello, W. Z. and Hines, M. E.: Application of static and dynamic enclosures for determining dimethyl sulfide and carbonyl sulfide exchange in Sphagnum peatlands: implications for the magnitude and direction of flux, J. Geophys. Res., 99, 14601-14607, 1994.

de Mello, W. Z.: Factors controlling fluxes of volatile sulfur compounds in Sphagnum peatlands, Ph. D. thesis, Univ. of New Hampshire, Durham, 1992.

Devai, I. and Delaune, R. D.: Formation of volatile sulfur compounds in salt marsh sediment as influenced by soil redox condition, Org. Geochem., 23, 283-287, doi:10.1016/01466380(95)00024-9, 1995.

Doerffel, K.: Statistik in der analytischen Chemie, 3rd Edition, Verlag Chemie, Weinheim, Germany, 1984.

Engel, A. and Schmidt, U.: Vertical profile measurements of carbonyl sulfide in the stratosphere, Geophys. Res. Lett., 21, 22192222, doi:10.1029/94GL01461, 1994.

Fried, A., Klinger, L. F., and Erickson III, D. J.: Atmospheric carbonyl sulfide exchange in bog microcosms, Geophys. Res. Lett., 20, 129-132, doi:10.1029/93GL00062, 1993.

Geng, C. M. and Mu, Y. J.: Carbonyl sulfide and dimethyl sulfide exchange between lawn and the atmosphere, J. Geophys. Res., 109, D12302, doi:10.1029/2003JD004492, 2004.

Goldan, P. D., Kuster, W. C., Albritton, D. L., and Fehsenfeld, F. C.: The measurement of natural sulfur emissions from soils and vegetation: three sites in the eastern United States revisited, J. Atmos. Chem., 5, 439-467, doi:10.1007/BF00113905, 1987.

Gries, C., Nash III, T. H., and Kesselmeier, J.: Exchange of reduced sulfur gases between lichens and the atmosphere, Biogeochemistry, 26, 25-39, doi:10.1007/BF02180402, 1994.

Hill, F. B., Aneja, V. P., and Felder, R. M.: A technique for measurement of biogenic sulfur emission fluxes, J. Environ. Sci. Heal. A, 13, 199-225, doi:10.1080/10934527809374804, 1978.

Hofmann, D. J.: Increase in the stratospheric background sulfuric acid aerosol mass in the past 10 years, Science, 248, 996-1000, doi:10.1126/science.248.4958.996, 1990.

Hofmann, U., Hofmann, R., and Kesselmeier, J.: Cryogenic trapping of reduced sulfur compounds using a nafion drier and cotton wadding as an oxidant scavenger, Atmos. Environ., 26A, 24452449, doi:10.1016/0960-1686(92)90374-T, 1992.

Kanda, K., Tsuruta, H., and Minami, K.: Emission of dimethyl sulfide, carbonyl sulfide, and carbon disulfide from paddy fields, Soil Sci. Plant Nutr., 38, 709-716, 1992.

Kesselmeier, J. and Merk, L.: Exchange of carbonyl sulfide (COS) between agricultural plants and the atmosphere: studies on the deposition of COS to peas, corn and rapeseed, Biogeochemistry, 23, 47-59, doi:10.1007/BF00002922, 1993.

Kesselmeier, J., Meixner, F. X., Hofmann, U., Ajavon, A., Leimbach, S., and Andreae, M. O.: Reduced sulfur compound exchange between the atmosphere and tropical tree species in southern Cameroon, Biogeochemisty, 23, 23-45, doi:10.1007/BF00002921, 1993.

Kesselmeier, J., Teusch, N., and Kuhn, U. Controlling variables for the uptake of atmospheric carbonyl sulfide by soil, J. Geophys. Res., 104, 11577-11584, doi:10.1029/1999JD900090, 1999.

Kettle, A. J., Kuhn, U., von Hobe, M., Kesselmeier, J., and Andreae, M. O.: Global budget of atmospheric carbonyl sulfide: Temporal and spatial variations of the dominant sources and sinks, J. Geophys. Res., 107, 4658, doi:10.1029/2002JD002187, 2002.
Khalil, M. A. K. and Rasmussen, R. A.: Global sources, lifetimes and mass balances of carbonyl sulfide (OCS) and carbon disulfide $\left(\mathrm{CS}_{2}\right)$ in the Earth's atmosphere, Atmos. Environ., 18, 18051813, doi:10.1016/0004-6981(84)90356-1, 1984.

Kluczewski, S. M., Brown, K. A., and Bell, J. N. B.: Deposition of $\left[{ }^{35} \mathrm{~S}\right]$-carbonyl sulphide to vegetable crops, Radiat. Prot. Dosim., 11, 173-177, 1985.

Kuhn, U., Ammann, C., Wolf, A., Meixner, F. X., Andreae, M. O., and Kesselmeier, J.: Carbonyl sulfide exchange on an ecosystem scale: soil represents a dominant sink for atmospheric COS, Atmos. Environ., 33, 995-1008, doi:10.1016/S13522310(98)00211-8, 1999.

Kuhn, U., Wolf, A., Gries, C., Nash III, T. H., and Kesselmeier, J.: Field measurements on the exchange of carbonyl sulfide between lichens and the atmosphere, Atmos. Environ., 34, 4867-4878, doi:10.1016/S1352-2310(00)00235-1, 2000.

Lamb, B., Westberg, H., Allwine, G., Bamesberger, L., and Guenther, A.: Measurement of biogenic sulfur emissions from soils and vegetation: application of dynamic enclosure methods with Natusch Filter and GC/FPD analysis, J. Atmos. Chem., 5, 469491, doi:10.1007/BF00113906, 1987.

Lehmann, S. and Conrad, R.: Characteristics of turnover of carbonyl sulfide in four different soils, J. Atmos. Chem., 23, 193207, doi:10.1007/BF00048260, 1996.

Liss, P. S. and Slater, P. G.: Flux of gases across the air-sea interface, Nature, 247, 181-184, doi:10.1038/247181a0, 1974.

Liu, G. S.: Soil physical and chemical analysis \& description of soil profiles, Standards Press of China, Beijing, China, 1996.

MacTaggart, D. L., Adams, D. F., and Farwell, S. O.: Measurement of biogenic sulfur emissions from soils and vegetation using dynamic enclosure methods: total sulfur gas emissions via MFC/FD/FPD determinations, J. Atmos. Chem., 5, 417-437, doi:10.1007/BF00113904, 1987.

Meixner, F. X., Fickinger, Th., Marufu, L., Serça, D., Nathaus, F. J., Makina, E., Mukurumbira, L., and Andreae, M. O.: Preliminary results on nitric oxide emission from a southern African savanna ecosystem, Nutr. Cycl. Agroecosys., 48, 123138, doi:10.1023/A:1009765510538, 1997.

Miller, A. G., Espie, G. S., and Canvin, D. T.: Use of carbon oxysulfide, a structural analog of $\mathrm{CO}_{2}$, to study active $\mathrm{CO}_{2}$ transport in the cyanobacterium Synechococcus UTEX 625, Plant Physiol., 90, 1221-1231, doi:10.1104/pp.90.3.1221, 1989.

Mu, Y. J., Geng, C. M., Wang, M. Z., Wu, H., Zhang, X. S., and Jiang, G. B.: Photochemical production of carbonyl sulfide in precipitation, J. Geophys. Res., 109, D13301, doi:10.1029/2003JD004206, 2004.

Mu, Y. J., Wu, H., Zhang, X. S., and Jiang, G. B.: Impact of anthropogenic sources on carbonyl sulfide in Beijing city, J. Geophys. Res., 107, 4769, doi:10.1029/2002JD002245, 2002.

Protoschill-Krebs, G. and Kesselmeier, J.: Enzymatic pathways for the consumption of carbonyl sulfide (COS) by higher plants, Bot. Acta, 105, 206-212, 1992.

Protoschill-Krebs, G., Wilhelm, C., and Kesselmeier, J.: Consumption of carbonyl sulfide by Chlamydomonas reinrardtii with different activities of carbonic anhydrase (CA) induced by different $\mathrm{CO}_{2}$ growing rates, Bot. Acta, 108, 445-448, 1995.

Protoschill-Krebs, G., Wilhelm, C., and Kesselmeier, J.: Consumption of carbonyl sulphide (COS) by higher plant carbonic anyhydrase (CA), Atmos. Environ., 30, 3151-3156, doi:10.1016/1352- 
2310(96)00026-X, 1996.

Roche, A. E., Kumer, J. B., Mergenthaler, J. L., Nightingale, R. W., Uplinger, W. G., Ely, G. A., and Potter, J. F.: Observations of lower-stratospheric $\mathrm{ClNO}_{2}, \mathrm{HNO}_{3}$, and aerosol by the UARS CLAES experiment between January 1992 and April 1993, J. Atmos. Sci., 51, 2877-2902, doi:10.1175/15200469(1994)051<2877:OOLSCH>2.0.CO;2, 1994.

Sandoval-Soto, L., Stanimirov, M., von Hobe, M., Schmitt, V., Valdes, J., Wild, A., and Kesselmeier, J.: Global uptake of carbonyl sulfide (COS) by terrestrial vegetation: Estimates corrected by deposition velocities normalized to the uptake of carbon dioxide $\left(\mathrm{CO}_{2}\right)$, Biogeosciences, 2, 125-132, 2005, http://www.biogeosciences.net/2/125/2005/.

Solomon, S., Sanders, R. W., Garcia, R. R., and Keys, J. G.: Increased chlorine dioxide over Antarctica caused by volcanic aerosols from Mount Pinatubo, Nature, 363, 245-248, doi:10.1038/363245a0, 1993.

Turco, R. P., Whitten, R. C., Toon, O. B., Pollack, J. B., and Hamill, P.: OCS, stratospheric aerosols and climate, Nature, 283, 283286, doi:10.1038/283283a0, 1980.

Van Diest, H. and Kesselmeier, J.: Soil atmosphere exchange of carbonyl sulfide (COS) regulated by diffusivity depending on waterfilled pore space, Biogeosciences, 5, 475-483, 2008, http://www.biogeosciences.net/5/475/2008/.
Watts, S. F.: The mass budgets of carbonyl sulfide, dimethyl sulfide, carbon disulfide and hydrogen sulfide, Atmos. Environ., 34, 761779, doi:10.1016/S1352-2310(99)00342-8, 2000.

Xu, X., Bingemer, H. G., and Schmidt, U.: The flux of carbonyl sulfide and carbon disulfide between the atmosphere and a spruce forest, Atmos. Chem. Phys., 2, 171-181, 2002, http://www.atmos-chem-phys.net/2/171/2002/.

Yang, Z., Kanda, K., Tsuruta, H., and Minami, K.: Measurement of biogenic sulfur gases emission from some Chinese and Japanese soils, Atmos. Environ., 30, 2399-2405, doi:10.1016/1352-2310(95)00247-2, 1996.

Yang, Z., Kong L., Zhang, J., Wang, L. and Xi, S.: Emission of biogenic sulfur gases from Chinese rice paddies, Sci. Total. Environ., 224, 1-8, doi:10.1016/S0048-9697(98)00207-1, 1998.

Yi, Z. G., Wang X. M., Sheng, G. Y., and Fu, J. M.: Exchange of carbonyl sulfide (OCS) and dimethyl sulfide (DMS) between rice paddy fields and the atmosphere in subtropical China, Agr. Ecosyst. Environ., 123, 116-124, doi:10.1016/j.agee.2007.05.011, 2008.

Yi, Z. G., Wang X. M., Sheng, G. Y., Zhang, D. Q., Zhou, G. Y., and Fu, J. M.: Soil uptake of carbonyl sulfide in subtropical forests with different successional stages in south China, J. Geophys. Res., 112, D08302, doi:10.1029/2006JD008048, 2007. 